\title{
1. Introduction: the comparative turn in constitutional theory
}

\author{
Gary Jacobsohn and Miguel Schor
}

\section{COMPARATIVE CONSTITUTIONAL THEORY}

Our subject is comparative constitutional theory. As editors of this book we would like to say what was once said in the first installment of a much more significant work: "The subject speaks its own importance."' Of course the author of this declaration, Alexander Hamilton, had such weighty matters as "the existence of the UNION" and "the fate of an empire" in the calculation that brought him to his summary view of The Federalist's significance to the task at hand. Nothing so consequential is at stake for us, but, beyond stating the obvious, we must address a preliminary question concerning what exactly it is our subject comprehends.

A proper response might begin with the issue Hamilton raises in Federalist \#1's opening paragraph, "whether societies of men are really capable or not of establishing good government from reflection and choice, or whether they are forever destined to depend for their political constitutions on accident and force."2 This question is as vital today as it was in the eighteenth century. The collapse of communism in Eastern Europe and authoritarianism in the Iberian Peninsula and Latin America led to renewed optimism about the possibilities of constitutional design at the end of the twentieth century. The populist, authoritarian headwinds buffeting long-standing democracies in the North Atlantic World in the twenty-first century, however, have undermined Whiggish views of democracy's progress while underscoring the continued importance of questions of design. The Federalist remains relevant to contemporary debates because it provides us with a methodology or a toolbox for thinking about problems of design that is grounded on reason and empirical observation. ${ }^{3}$ The activity that today is conducted under the designation constitutional design is in no small measure attributable to the success of Publius' earlier effort.

As one of our contributors, Stephen Tierney, writes in his chapter for this volume, "Constitutional theory is concerned with the notion of a well—or poorly-functioning

1 The Federalist No. 1 (Alexander Hamilton).

2 Id. As Sanford Levinson points out, "No sentence more marks Publius as child of the Enlightenment." Sanford Levinson, An Argument Open to All: Reading The Federalist in the 21st Century 9 (2015).

3 Miguel Schor, The Federalist as a Primer on Constitutional Design: A Critical Appraisal of Separation of Powers and Written Constitutionalism (2017) (unpublished manuscript) (on file with author) [hereinafter Schor, The Federalist]. 
constitution." ${ }^{4}$ In this sense, of course, what Publius was doing must be considered constitutional theorizing, since The Federalist was written to win support for a constitution that was crafted to function better than the one it was intended to replace. ${ }^{5}$ Many of the essays in our collection are similarly preoccupied with the question of how to enhance the performance of constitutional governance, but the scholarly lens through which they examine their objects of inquiry opens up to a wider field of vision than we see in The Federalist. Contemporary theorists undoubtedly have a much richer constitutional data set to draw on than did Madison and Hamilton. The problems that drove the debate over constitutional design in the eighteenth century, moreover, have been reimagined and reconceptualized or have receded in importance as new problems and issues surfaced. ${ }^{6}$

In addressing his arguments to his "fellow citizens", all the while reassuring them that these arguments were directed toward the "political prosperity" of his audience, Publius did more than affirm the obvious, that his effort was a political exercise in persuasion rather than a treatise on political or constitutional theory. He also pioneered an approach to arguing about constitutions that may be seen, despite its attention to the lessons that might be drawn from the experience of other nations, as a precursor for understanding the activity of constitutional theory as a characteristically parochial enterprise. For example, David Strauss has suggested, "We can best understand constitutional theory ... if we see it as an exercise in justification ... The justification is addressed to people of a particular culture." 7 If the authors of The Federalist constructed their case for the adoption of a Constitution on the foundation of a set of ideas - foremost of which was that "the people must cede to [government] some of their natural rights" ciples of government", ${ }^{9}$ the modern academic discipline of constitutional theory, as Strauss points out citing John Rawls, "proceeds from what all parties to the discussion [over justification] hold in common."10

What they hold in common need not of course lead these parties to similar conclusions. The most Rawlsian of constitutional theorists, Ronald Dworkin, said in reference to the United States, "Our constitutional system rests on a particular moral theory, namely, that men have moral rights against the state." 11 Realizing that "even reasonable men of good will differ when they try to elaborate ... the moral rights that the due process clause or the equal protection clause brings into the law"12 does not obviate the fact of it being "our" system that is the object of constitutional theorizing.

4 Stephen Tierney, Federalism and Constitutional Theory, in Comparative Constitutional Theory (Gary Jacobsohn and Miguel Schor eds., 2017).

5 John P. Roche, The Founding Fathers: A Reform Caucus in Action, 55 Am. Pol. Sci. Rev. 799 (1961).

6 Mark Tushnet, Advanced Introduction to Comparative Constitutional Law (2014).

7 David A. Strauss, What is Constitutional Theory?, 87 Cal. L. Rev. 581, 582 (1999).

8 The Federalist No. 2 (John Jay).

9 Id.

10 Strauss, supra note 7, at 583 (citing John Rawls, A Theory of Justice 580-81 (1971)).

11 Ronald Dworkin, Taking Rights Seriously 147 (1977) [hereinafter Dworkin, Taking Rights Seriously].

12 Id. at 133. 
In the American case this sets broad parameters for the inevitable disagreement among constitutional theorists, who are amidst the particularities of their differences committed to specific points of common jurisprudential attachment: for example, that the constitutional text matters and that the intentions of its framers is of some importance. ${ }^{13}$

In this connection another characteristic of American constitutional theorizing-its juri-centric focus-may reinforce parochial tendencies. Dworkin exemplifies the familiar emphasis on the judiciary as the institutional hub for theorizing about things constitutional. In this court-centered model the judge, idealized in Dworkin's Herculean philosopher-jurist, is guardian and expositor of the moral principles that structure and guide the nation's constitutional development. ${ }^{14}$ The theory of adjudication that follows from this role designation is one that "identifies a particular conception of community morality as determinative of legal issues; that conception holds that community morality is the political morality presupposed by the laws and institutions of the community." 15 If constitutional theory is mainly about achieving an interpretive stance to enable judges "to fit and justify the most basic arrangements of political power in the [i.e., their] community", 16 then the resulting insularity of the specific enterprise is anything but surprising. We can see as much in Jeremy Waldron's critique of Dworkin's regard for "judges as moral reasoners", in which Waldron argues that this dominant jurisprudential mindset can easily obscure an awareness that "watershed" constitutional issues "are not peculiar to the society in which they arise; they do not arise just because we happen to be saddled with this or that scrap of unclear text or this or that indeterminate line of doctrine." Instead, "[t]hey define the major choices that any modern society must face, choices that are the focal point of moral and political disagreements in many societies." 17

Developments on the ground only underscore Waldron's empirical observation. Increasing awareness of the ubiquity of the challenges confronting constitutional thinking is a common theme in a post-1989 world so prominently marked by momentous transitions from authoritarianism to democracy, by multiple constitutional revolutions and devolutions, by the increased penetration of international law into national jurisdictions, and by the enhancement of supra-national institutions of governance. All of this has led to greater scholarly and juridical attention to comparative

13 Strauss, supra note 7, at 583. Strauss argues as well that there is also agreement about relatively concrete matters, most notably the legitimacy of Brown v. Board of Education. On the importance of the text, Richard Fallon points out that "even the most paradigmatically practice-based theory must acknowledge that American constitutional practice has a text at its center." Richard H. Fallon Jr., How to Choose a Constitutional Theory, 87 Cal. L. Rev. 536, 544 (1999).

14 Dworkin, Taking Rights Seriously, supra note 11, at 105-30; Ronald Dworkin, Law's Empire (1986) [hereinafter Dworkin, Law's Empire]. The Indian legal theorist, Upendra Baxi, has called attention to the limited reach of Dworkin's theory, particularly when applied to the experience of postcolonial constitutionalism. Upendra Baxi, A Known But an Indifferent Judge: Situating Ronald Dworkin in Contemporary Indian Jurisprudence, 4 Int'1 J. Const. L. 557 (2003).

15 Dworkin, Taking Rights Seriously, supra note 11, at 126.

16 Dworkin, Law's Empire, supra note 14, at 380.

17 Jeremy Waldron, Judges as Moral Reasoners, 7 Int'1 J. Const. L. 2, 22 (2009). 
constitutional law and has triggered a vigorous debate-much more so in the United States than elsewhere-over the relevance and efficacy of foreign legal sources to domestic adjudication. ${ }^{18}$ Oddly, however, it has not been the occasion for much advancement in the development of comparative constitutional theory. ${ }^{19}$

To be sure, our efforts to address this deficit can hardly be considered unprecedented. One notable earlier occasion for filling it coincided with the crisis of the Weimar Republic. Indeed, the theorizing occurring in connection with this watershed moment in German history has been compared to The Federalist in terms of its importance as "an essential source for thinking" about the state and democracy within their respective countries. ${ }^{20}$ Unlike the authors of The Federalist, who shared a common philosophical outlook, the Germans were a disparate group, each one of which having experienced the vehemence of a fellow member's fiercely combative writings. Most controversial among this circle was Carl Schmitt, who was an important early voice for the theoretical orientation featured in this book.

The stimulus for this more comparative theoretical approach grew out of an important facet of the reality confronting Schmitt and the other theoreticians of his time: "Weimar democracy was not developed through exchange with the French, English, or American democratic traditions, but with an eye to its own past." 21 Schmitt in particular turned his attention to these other traditions; as two careful students of his work have noted:

Schmitt seeks to shift the center of gravity of legal theory debates away from the analysis of individual provisions of the Weimar Constitution by examining the Constitution in a much broader comparative historical framework, one in which the issue of practical relevance of the resulting normative concepts is addressed directly through the process of concept formation. ${ }^{22}$

Indeed Schmitt signals this shift in the opening pages of Constitutional Theory, asserting that unlike other works that focus on "individual lands", the intention of his effort is "to offer a systematic framework", which stands "in contrast to the breaking down of a unified subject into individual investigations." 23 So, for example, Schmitt begins his chapter on parliamentary governance by commenting on the ambiguity of the term, "parliamentarianism", pointing out that the English constitutional model is

18 Miguel Schor, Mapping Comparative Judicial Review, 7 Wash. U. Global Stud. L. Rev. 257, 278-84 (2008) [hereinafter Schor, Mapping].

19 Oddly because, as Michel Rosenfeld and Andras Sajo have noted, "comparison was intended to highlight theoretical trends ..." Michel Rosenfeld and Andras Sajo, Introduction, in The Oxford Handbook of Comparative Constitutional Law 7 (2012).

20 Arthur J. Jacobson and Bernhard Schlink, Constitutional Crisis: The German and the American Experience, in Weimar, A Jurisprudence of Crisis 3 (Arthur J. Jacobson and Bernhard Schlink eds., 2000).

21 Id. at 17.

22 Jeffrey Seitzer and Christopher Thornhill, An Introduction to Carl Schmitt's Constitutional Theory: Issues and Context, in Carl Schmitt, Constitutional Theory 28 (Jeffrey Seitzer trans. and ed., 2008). As Seitzer and Thornhill point out, Schmitt's comparative focus was in marked contrast to Gerhard Anschutz's classic commentary on the Weimar Constitution, which largely ignored the comparative mode of inquiry.

23 Constitutional Theory, supra note 22, at 54. 
widely viewed as the "ideal scheme" for this particular arrangement of the law-making function.

But everywhere the greatest differences manifest themselves despite the common model. Thus, different features emerge as definitive characteristics of 'parliamentarianism,' and if a constitutional regime speaks of the dependence of the government on parliament, of 'responsibility,' or 'confidence,' these words have an entirely different sense in various countries and eras. ${ }^{24}$

What follows is an extended discussion of the differences between the political situations of England and the European continent, with Schmitt concluding that a fixation on the English model as manifesting the essential attributes of the subject in question represented a "substitu[tion] for reflection and political theory among many politicians and theorists." 25 For Schmitt, the main cost of not considering the comparative historical landscape was quite tangible: a failure to secure "a politically efficacious form of constitutional theory." 26

Although the contributions to this volume often speak to practical problems of constitutional governance, Schmitt's fixation with the daunting challenges confronting one particular constitutional polity is not what we are after here. Like the German theorist, we appreciate the connection between practical relevance and concept formation, yet our principal concern is with the latter, or perhaps more modestly, with the clarification of concepts important to the activity of comparative theorizing (which if done well will translate into a more applied vernacular). Thus many of the ideas and analytical constructs that have become ubiquitous in the field of comparative constitutional law remain largely under-theorized, frequently applied to all manner of things that are dissimilar in significant respects. Parliamentarianism is surely one of these, but so too are many of the other phenomena discussed in this book, for example: federalism, judicial supremacy, socio-economic rights, constituent power, constitutional revolution, dignity and proportionality.

For issues of this sort there is one theoretical conundrum that runs through the broad array of comparative-related topics discussed in these pages: the degree to which problems of constitutional import should be approached from a universalist perspective on the assumption that constitutionalism rightly understood calls for solutions common to all polities; and the extent to which these problems are best understood in terms of their particularity, a view based on the countervailing assumption that constitutional challenges can only be met with an acceptance of the intractable limitations imposed by culture and history. Jeremy Bentham pioneered the former approach to comparative law; Montesquieu the latter approach. Today this debate is frequently framed in terms of the "large C" and "small c" constitutions. ${ }^{27}$ A nation's formal or large C constitution undoubtedly contains autochthonous elements but it is also the product of the global expansion of constitutionalist ideas and reflects universalist principles. A polity's small

\footnotetext{
$24 \quad I d$. at 328.

25 Id. at 331.

26 Seitzer and Thornhill, supra note 22, at 34.

27 David S. Law, Constitutions, in The Oxford Handbook of Empirical Legal Research 378 (Peter Cane and Herbert Kritzer eds., 2010).
} 
c constitution, on the other hand, is the product of autochthonous developments that are reflected in the practices, understandings and beliefs that instantiate a constitutional text. $^{28}$ To be sure, the task here is not one of choosing between mutually exclusive intellectual approaches to constitutionalism, but rather of achieving a functional balance between alternative ways of imagining constitutional configurations. The universal/ particular polarity is, we believe, a false dichotomy; to elude its misleading implications we would do well to borrow from Schmitt and require the reconciling of a concept's "definitive characteristics" with its different manifestations.

The hope, then, is that the exertions of constitutional theorists with a comparative bent will culminate in just such reconciliation. To make it a reality one might begin with the simple recognition that there are constitutional principles and values that embody precepts of political morality rooted in a nation's past, whose meaning derives from experience within a specific political and cultural context, and whose reach may not extend far beyond that local context, if at all. Other principles make a claim of universality, such that the moral truths they are said to embody are precisely the ones whose recognition is required for a constitution to exist in more than name only. Their success or failure in concrete application will depend on how they are adapted to the circumstances and contexts of a given time and place. This adaptation entails absorbing and integrating values from the society's dominant traditions, culminating in some modification in the scope and depth of constitutional principles without leaving them transformed with respect to their underlying and most fundamental commitments. ${ }^{29}$

Sometimes the jurisprudential response to the tensions that result from the presence of these two types of principles is to accept the tension as an enduring component of the constitutional predicament, a posture that incorporates the implicit understanding of a nation's constitutional identity as one that develops dialogically, thereby entailing interpretive and political activity reflective of the inevitable disharmonies endemic to the constitutional condition. ${ }^{30}$ Comparative constitutional theory cannot ignore this

28 Although written constitutions have become nearly universal, the classic British Constitution remains an outlier and provides a nearly unique example of how an autochtonous, small $\mathrm{c}$ constitution that is not cabined by a text operates. Martin Loughlin, The British Constitution: a Very Short Introduction (2013).

29 This process received its classic formulation with Edmund Burke, who saw constitutions as embodiments of unique histories and cultural traditions. His emphasis on particularities and prescription, and on the constitution as something that evolves to conform to the circumstances and habits of a people, is upon first glance suggestive of a moral sensibility strongly deferential to entrenched cultural norms. But the deference was not unqualified, as illustrated in Burke's rejection of Warren Hastings' main argument for his morally questionable actions in India. Hastings had framed a defense of "geographical morality", which held that whatever happened in India was compatible with local customs and therefore could not be judged by external standards. Burke was categorical in rejecting this moral perspective, arguing in response that the governance of Indians had to respect the same universal laws of right conduct that applied to Englishmen. Necessary, for Burke, was a prudential balancing of the universal and the particular. "The foundations of government [are ... in the constitution] laid ... in political convenience and in human nature; either as that nature is universal, or as it is modified by local habits." Francis Canavan, Prescription of Government, in Daniel Ritchie, Edmund Burke: Appraisals and Applications 259 (1990).

30 This point is explored at length in Gary Jeffrey Jacobsohn, Constitutional Identity (2010). 
activity, which is to say that progress towards the goal of conceptual clarity must be accompanied by a commitment to the empirical effort required to make sense of the many such adaptations occurring in all constitutionally organized polities. As has been correctly noted with respect to American legal scholarship, there is a "disconnect between normative constitutional theory and the empirical realities of constitutional practice." 31 Much as connecting the two should be a priority for constitutional theorists working within a specific national context, comparativists too would be remiss if they did not demonstrate a similar commitment.

The readers of this volume will find in its pages a compendium of theory-driven essays that seek to understand how these distinctive constitutional realities are critical to the activities of constitutional design and interpretation. The aspirational or expressive dimension of large $\mathrm{C}$ constitutions, whether representing seriously inscribed potentially attainable goals, or dubiously incorporated objectives of mainly decorative significance, looms large in the development of conceptually rich renderings of comparative constitutional experience. ${ }^{32}$ The idea, traceable to Aristotle, that a constitution defines the principles of justice toward which a people aspire, is the basis for claiming that aspirational considerations should weigh heavily in determining constitutional policies and meanings. Contemporary accounts of the workings of constitutional arrangements, but also the iconic version that accompanied the arrival of modern constitutionalism, largely avoid the Aristotelian distinction between a country's actual constitution and the ideal constitution; still, the distinction between the actual written charter and the facts-on-the-ground functioning constitutional order parallels the earlier division in establishing a mode of inquiry informed by the sobering reality of the inevitable breach between what we have and what we aspire to be. Thus Publius concluded his series of papers by declaring: "I am persuaded that it [the Constitution] is the best which our political situation, habits, and opinions will admit." 33 It remained for his successors to investigate the numerous ways in which even this imperfect instrument provided at best a partial blueprint for organizing the nation's business.

We might think of the contributors to this volume as engaged in a similar enterprise, only with a broader scope of inquiry. These efforts comprise, as Ran Hirschl has observed in his insightful account of the several approaches that are driving "the renaissance of comparative constitutional law", a "mode of comparative constitutional scholarship involv[ing] a quest for a detailed understanding of how people living in different, cultural, social, and political contexts deal with constitutional dilemmas that are assumed to be common to most modern political systems." 34 If concept formulation is the proximate goal of much of this work, its underpinning is an empirically-based

31 Andrew Coan, Toward a Reality-Based Constitutional Theory, 89 Wash. U. L. Rev. 273, 276 (2011).

32 As Walter Murphy argued, "If a civil society is to have a charter, it must not only lay down rules for a government but also articulate many of the basic principles, values and aspirations that will reconstitute people from a collection of humans sharing a common geography into citizens sharing a common creed." Walter F. Murphy, Constitutional Democracy: Creating and Maintaining a Just Political Order 198 (2006).

33 The Federalist No. 85 (Alexander Hamilton).

34 Ran Hirschl, Comparative Matters: The Renaissance of Comparative Constitutional Law 238 (2014). 
assessment of the core features of constitutional practice within a cross-national context, and its longer-term vision entails the prospect of vigorous debate over the concrete implications of conceptual formulation, as well as the construction of theoretically informed propositions suitable for further investigation.

\section{THE CHAPTER STUDIES}

Although The Federalist made pioneering use of empirical evidence in defending the plan of the convention to the American people, it is the Constitution that undoubtedly plays a much larger role in the constitutional imagination. The idea of a written constitution grounded on the constituent power of the people spread virally throughout the Atlantic world in the nineteenth century and globally in the twentieth. ${ }^{35}$ Judicial review and federalism also spread in the nineteenth century but neither institution became a firm fixture of constitutional democracies until after World War II. ${ }^{36}$ Today it has become virtually unthinkable that a liberal democracy might lack a written constitution enforced by judges or that power is not divided in some fashion.

The American Constitution, however, is no longer the preeminent model for constitution writers around the globe. As one of our contributors, David Law, has argued, the American Constitution is similar to the beta version of software and polities around the globe have understandably turned to newer, updated versions of constitutions as models. ${ }^{37}$ The Constitution-as yet another of our contributors, David Robertson, has argued-continues, however, to provide an intellectual overhang that colors how scholars around the globe think about constitutionalism. ${ }^{38}$ This intellectual influence is attributable to three factors: the longevity of the Constitution; its "success" in facilitating democratic politics for over two centuries; 39 and the depth and intellectual quality of Supreme Court decisions and of American constitutional scholarship.

The Parts of this book reflect the long intellectual shadow cast by the United States' Constitution over comparative constitutional theory. Part I addresses issues that arise from a constitutional text. Although written constitutions were celebrated in the late eighteenth century for empowering and limiting government, ${ }^{40}$ their "efficient secret" is

35 George Athan Billias, American Constitutionalism Heard Around the Globe, 1787-1989 (2009).

36 Schor, Mapping, supra note 18; Tierney, supra note 4.

37 David S. Law and Mila Versteeg, The Declining Influence of the United States Constitution, 87 N.Y.U. L. Rev. 762 (2012).

38 David Robertson, The Judge as Political Theorist: Contemporary Constitutional Review (2010).

39 The Constitution may, of course, not be the primary factor in the success of the American experiment in self-government but there can be little doubt that the success of that experiment lent legitimacy to the Constitution as an intellectual construct worthy of study around the globe.

40 Thomas Paine, Rights of Man: Being an Answer to Mr. Burke's Attack on the French Revolution (Prometheus Books 1987) (1791). 
that they structure conflict along certain paths. ${ }^{41}$ Some of these paths-namely those dealing with political conflict-are reasonably well mapped out in constitutional texts whereas some of these paths - namely those dealing with constitutional conflict-are fought over terrain that was not designed for such battles.

Part II concerns issues of judicial interpretation. Although written constitutions need not give rise to judicial review, courts around the globe have successfully used constitutional text to enhance their power by seeking to resolve disputes that would otherwise be handled by the political branches. Part III focuses on the foundational problems of constitutional change and constituent power. Written constitutions formally vest the power to found and change constitutions in the people which generates theoretical and practical problems. Part IV reminds us of the limits of written constitutions as many crucial questions of constitutional theory arise when the text runs out.

\section{A. Constitutional Structure and Rights}

Constitutions structure disagreement in part by distinguishing ordinary from constitutional politics while leaving underdetermined the issue of how constitutional disagreement is to be resolved. As a practical matter, courts have stepped into this lacuna to claim that they have the power to resolve constitutional disputes. Scholars dispute whether courts enjoy supremacy when engaging in constitutional interpretation or whether the process involves numerous actors and is therefore "dialogical". Stephen Gardbaum in What is judicial supremacy? ${ }^{42}$ provides analytical clarity by disentangling the ways scholars analyze the authority of courts to interpret constitutions. He identifies four meanings of supremacy: interpretive, attitudinal, decisional and political. The first two focus on constitutional culture. Gardbaum examines whether judicial decisions are binding on other actors and whether courts are programmatic in interpreting the constitution. The second two meanings focus on the mechanisms available to political actors and citizens to respond to decisions they disagree with. Gardbaum concludes that the term judicial supremacy is useful but that scholars should disaggregate the term along the lines he suggests before employing it.

Torres Perez and Schor analyze the problem of collaboration in constitutional interpretation. Torres Pérez examines inter-judicial dialogue ${ }^{43}$ whereas Schor examines inter-branch dialogue. ${ }^{44}$ Torres Pérez examines the interplay of national and supranational courts in interpreting European declaration of rights instruments. In a succinct exposition of the phenomenon of dialogue, she argues that the term is best "understood

41 It was Walter Bagehot, the British journalist and political scientist, who first pointed out the important distinction between the ceremonial and efficient aspects of constitutions. Walter Bagehot, The English Constitution (Cornell Univ. Press 1986) (1872 2d ed.).

42 Stephen Gardbaum, What is judicial supremacy, in Comparative Constitutional Theory, supra note 4.

43 Aida Torres Pérez, Judicial Dialogue and Fundamental Rights in the European Union: A Quest for Legitimacy, in Comparative Constitutional Theory, supra note 4.

44 Miguel Schor, Constitutional Dialogue and Judicial Supremacy, in Comparative Constitutional Theory, supra note 4. 
as an exchange of arguments between courts regarding the interpretation of fundamental rights." 45 The legitimacy of judicial decisions is enhanced since it is the product of a collaborative effort. Schor examines inter-branch dialogue by comparing a constitutional system that (almost) entrenches judicial supremacy-the United Stateswith a constitutional system that seeks to reconcile judicial with legislative supremacy-Canada. He concludes that enhancing the mechanisms by which political actors can respond to judicial decisions they disagree with has a democratic pay-off. Weaker courts are less likely to engender social conflict as they are more likely to facilitate negotiation and consensus over constitutional meaning.

Although constitutional framers give little thought to conflict over constitutional meaning, the problem of political conflict looms large in the constitutional imagination. Constitutional framers around the globe have spent considerable energy focusing on how written instruments structure ordinary politics by dividing authority vertically and horizontally. Stephen Tierney provides an incisive account of vertical separation of powers. ${ }^{46}$ He notes that while political scientists have dominated comparative discussions of federalism, federalism is in its origins a constitutional idea that deals with the practical problem of accommodating national and state power. Federalism expanded enormously following World War II in part because it was adopted in Germany-which has proven a highly influential global constitutionalist model-and in part because federalism was pressed into service to deal with the ethnic and linguistic cleavages that were endemic to newly independent nations in Africa and Asia. The problem, Tierney concludes, is that to recover federalism as a comparative constitutionalist idea, scholars must both liberate the concept from its long association with the United States and disentangle it from political science accounts that largely downplay the constitutional aspects of federalism.

Perhaps no idea advanced by the framers of the American constitution has proven as monumental on the world stage or as institutionally complex as horizontal separation of powers. Cheryl Saunders "seeks to tease out some of the principal variations in approaches to separation of powers." 47 The idea developed from a "vibrant, transnational exchange of ideas in reaction to autocratic government in the seventeenth and eighteenth centuries." 48 She observes that the basic building blocks of separation of powers - the idea that judicial, executive and legislative powers are distinct-can be blended in different ways as illustrated by the experience of the United Kingdom with parliamentary government, the United States with presidential government and France with semi-presidentialism. Saunders notes that theory is informed by historical experience that unfolds organically along national lines and provocatively suggests that we know too little about the interplay between a nation's small and large $\mathrm{C}$ constitution to be fully confident in our assessment of comparative constitutional theory.

The United States, of course, is no longer the premier global constitutional model, a development that is nicely illustrated by three chapters that focus on important new

\footnotetext{
45 Torres Pérez, supra note 43.

46 Tierney, supra note 4.

47 Cheryl Saunders, Theoretical Underpinnings of Separation of Powers, in Comparative Constitutional Theory, supra note 4 .

48 Id.
} 
issues of comparative constitutional theory. Janet L. Hiebert tackles the problem of parliamentary bills of rights that have been adopted in some of the polities of the British commonwealth. ${ }^{49}$ These bills of rights seek to accommodate judicial review to the strong role traditionally played by parliament in construing rights. She argues that the long tradition of parliamentary control over rights has persisted in spite of the enactment of formal bills of rights since governments seek to preserve their legislative programs against potential judicial encroachment.

Hiebert focuses on new structural developments; Jacob Weinrib and Jeff King, on the other hand, write about post-World War II rights developments. Weinrib's subject is human dignity, which is undoubtedly one of the two most important rights developments of post-war constitutional discourse. ${ }^{50} \mathrm{He}$ observes that the term human dignity is at once both "upheld in jurisdictions around the world as the animating principle of postwar constitutionalism" and criticized for a "multitude of sins." 51 Weinrib responds to the critics by arguing that the term dignity does too much practical work for it to be dismissed for theoretical reasons. What is needed, he argues, is a theory that underpins the "modern constitutional project." 52 Jeff King examines the other key post-war shift in rights which is the movement towards the realization of social rights. ${ }^{53}$ He notes that this movement was hampered in the United States and the United Kingdom by the view that there was an irreducible tension between liberty and social rights. King situates "thinking about social rights in the broader tradition of constitutionalism" by examining how they "have an indirect" rather than a "directly enforceable impact on securing social entitlements." 54

\section{B. Constitutional Interpretation}

It is ironic that the most important theoretical influence of the American Constitution flows from a constitutional development that forms part of America's unwritten constitution, namely judicial review. What judges do has become the principal stuff of constitutional theorizing around the globe. David Robertson takes on one of the animating principles of American constitutional theory by subjecting the countermajoritarian thesis to withering comparative criticism. ${ }^{55}$ The counter-majoritarian difficulty as formulated by Alexander Bickel posited that courts are a deviant institution in a democracy and that judicial review must, therefore, be justified in some fashion. ${ }^{56}$ Robinson argues that what gives this view particular salience in the United States is a

49 Janet L. Hiebert, Parliamentary Bills of Rights: Have they Altered the Norms for Legislative Decision-Making? in Comparative Constitutional Theory, supra note 4.

50 Jacob Weinrib, Human Dignity and its Critics, in Comparative Constitutional Theory, supra note 4.

51 Id.

52 Id.

53 Jeff King, Social Rights in Comparative Constitutional Theory, in Comparative Constitutional Theory, supra note 4.

54 Id.

55 David Robertson, The Counter-Majoritarian Thesis, in Comparative Constitutional Theory, supra note 4.

56 Alexander Bickel, The Least Dangerous Branch (1962). 
loss of faith in courts motivated by legal realism. He contrasts this loss of faith with the view that holds sway in Europe, which is that judicial review was adopted because it was believed that courts would "civilize the legislature." 57 Post-war constitutions were written to break with the past and it was widely understood that courts would play a critical role in joining the "struggle" to overcome the past by articulating and developing constitutional values. ${ }^{58}$ In short, and somewhat paradoxically, American scholars tend to emphasize the word democracy and Europeans the word constitutional when theorizing about the role of judges in a constitutional democracy.

Bickel's formulation of the counter-majoritarian difficulty puts into sharp relief the problem of judicial reasoning. David Landau and Victor Ferreres Comella ably tackle this problem but approach it from different directions. Landau examines legal pragmatism, which is generally considered a peculiarly American legal theory of adjudication, and argues it has important comparative dimensions. ${ }^{59}$ Pragmatism "envisions judging" as a practical "problem-solving enterprise" that is highly contextual in its use of theory. ${ }^{60}$ Landau argues that this style of adjudication should play a crucial role globally particularly in the global legal South where courts are faced with the problem of progressively realizing constitutional values under difficult circumstances. Victor Ferreres Comella analyzes proportionality, which has "become part of the constitutional grammar of rights at the global level", except in the United States. ${ }^{61}$ Proportionality rests on three prongs: suitability, necessity and balancing. Ferreres persuasively argues that each of these prongs rests on a substantive theory of justice and rights. Consequently, political actors should take ideology into account in judicial selection and constitutional framers should give thought to the problem of checks and balances when it comes to constitutional interpretation.

Howard Schweber and Heinz Klug examine the problem of cross-national jurisprudence. Schweber examines how apex courts rely on textualism by comparing religious establishment cases in a constitutional system that has an establishment clause, the American Constitution, and in a constitutional system lacking such a clause, the European Convention on Human Rights. ${ }^{62}$ Schweber concludes that the "relationship to a text is a key variable that operates independently of other typologies of constitutional reasoning." 63 Heinz Klug seeks to "develop a theoretical understanding of the impact of context in shaping the role of cross-national jurisprudence in national courts and politics." 64 He concludes that disagreements over the use of foreign legal sources are deeply tied to ideas of constitutional identity.

57 Robertson, supra note 55.

$58 \quad$ Id.

59 David Landau, Legal Pragmatism and Comparative Constitutional Law, in Comparative Constitutional Theory, supra note 4.

60 Id.

61 Victor Ferreres Comella, Beyond the Principle of Proportionality, in Comparative Constitutional Theory, supra note 4.

62 Howard Schweber, Text and Textualism: Religious Establishment in the U.S. Supreme Court and the European Court of Human Rights, in Comparative Constitutional Theory, supra note 4. 63 Id.

64 Heinz Klug, Reception, Context, and Identity: A Theory of Cross-National Jurisprudence, in Comparative Constitutional Theory, supra note 4. 


\section{Constitutional Change}

The most significant break that revolutionaries throughout the Atlantic world made with monarchy was grounding the legitimacy of their newly adopted written texts on the constituent power of the people. Yaniv Roznai and Mark Tushnet write about constituent power. Yaniv Roznai disaggregates the theoretical problems raised by the notion of a constituent power. ${ }^{65} \mathrm{He}$ argues that though the term "remains vague, elusive, and open to abuse", it should not be abandoned but further developed by theorists as the "generative principle of modern constitutional arrangements." 66 Mark Tushnet turns to another aspect of the constituent power, the power of amendment. ${ }^{67}$ He observes that there is a tension between the constituent power and formal provisions for amendments since the latter will sometimes thwart the former. He concludes that legal limits to amendments are "prudential" rather than "legally binding." 68

Gary Jacobsohn focuses on Germany and India to examine the tension between constitutional revolutions and constitutional identity. ${ }^{69} \mathrm{~A}$ constitutional revolution rests on a sharp shift in how constitutions are conceptualized; constitutional identities flow from incremental changes that are at once both anchored in the past and sail into the future. The German and Indian Constitutions were adopted within six months of each other, and both marked a revolutionary change from the past. The high courts of the two polities pioneered the idea of an unconstitutional amendment. Jacobsohn concludes that the idea of an unconstitutional amendment elevates the idea of "constitutional identity" to one of "jurisprudential significance."70 It is also a jurisprudential attempt to limit the constituent power of the people engaged in an ongoing constitutional project of reconstruction.

Joel Colón-Ríos and Gabor Halmai approach the problem of constituent power from the perspective of developing nations. Joel Colón-Ríos articulates the theoretical bases of formal constitutional change and then provides a typology of constitutional amendment in Latin America that he uses to "identify the unstated theoretical bases of these different [theoretical] approaches to formal constitutional change." $71 \mathrm{He}$ concludes that our theoretical conceptions of formal amendment do not fully explain or exhaust the mechanisms used to effectuate formal constitutional change in the region. Gábor Halmai examines the theoretical problems raised by the legal regulation of transitional justice in the negotiated transitions that occurred in Eastern Europe,

65 Yaniv Roznai, "We the People," "Oui, the People," and the Collective Body: Perceptions of Consituent Power, in Comparative Constitutional Theory, supra note 4.

66 Id.

67 Mark Tushnet, Amendment Theory and Constituent Power, in Comparative Constitutional Theory, supra note 4.

68 Id.

69 Gary Jacobsohn, Anchoring and Sailing: Contrasting Imperatives of Constitutional Revolution, in Comparative Constitutional Theory, supra note 4.

70 Id.

71 Joel Colón-Ríos, Theorizing about Formal Constitutional Change: the Case of Latin America, in Comparative Constitutional Theory, supra note 4. 
1989-1990. ${ }^{72}$ The practical problem of rectifying the injustices of the old order during a period of constitutional transition illustrates the tensions between the rule of law and notions of justice.

\section{Issues in Constitutionalism}

Although the term constitutionalism is commonly used to refer to normative arguments about constitutions, that is an impoverished use of the term. As Publius well understood, empirical, historical and comparative data are crucial in assessing constitutional design. Constitutionalism has also become a residual category for issues and concepts that do not fit into the neat box provided by a written constitution. All codifications suffer from gaps which generate considerable theoretical disagreement over how those lacunae are to be filled. ${ }^{73}$ Both uses of the term are in full display in the chapters in this section.

A core problem for comparative constitutional theory is how to account for unwritten constitutions. Janet McLean forthrightly begins her chapter by asking "Should unwritten constitutions even have a place in a book about constitutional theory?"74 McLean argues that unwritten and written constitutions are not categorically different as there is a continuum depending on the degree and importance of "writtenness" in a constitutional culture. Unwritten constitutions, moreover, have important lessons for constitutional theorists since a focus on history, not constitutional text, is crucial in making well founded judgements about contemporary political arrangements. McLean provocatively concludes that the real lesson of unwritten constitutions is that scholars should focus on comparison rather than theory by providing historically grounded accounts of constitutions.

The relationship between constitutions and citizens is taken up by Jan-Werner Müller and John Finn. Müller focuses on how constitutional democracies might best defend themselves against pressure from below. ${ }^{75} \mathrm{He}$ argues that the mechanisms of militant democracy that restrict the ability of majorities to govern may properly be used to protect the core of a constitutional project, namely its identity, as long as it prevents "authoritarian populist projects" and is not used as a "sword" against unpopular minorities. Finn begins by observing that citizens create constitutions and constitutions citizens. ${ }^{76} \mathrm{He}$ questions whether the renewed focus on participatory constitutionmaking is likely to result in constitutional orders in which citizens have the attitudes and mores needed to sustain constitutionalism. The problem is that constitutional

72 Gábor Halmai, Transitional Justice, Transitional Constitutionalism and Constitutional Culture, in Comparative Constitutional Theory, supra note 4.

73 Contemporary American constitutional theory, for example, is deeply divided over the relative weight to be afforded historical, contemporary, and comparative arguments in plugging constitutional gaps. See, e.g., N.L.R.B. v. Canning, 134 S. Ct. 2550 (2014).

74 Janet McLean, The Unwritten Constitution, in Comparative Constitutional Theory, supra note 4 .

75 Jan-Werner Müller, Militant Democracy and Constitutional Identity, in Comparative Constitutional Theory, supra note 4.

76 John E. Finn, Some Notes on Inclusive Constitution Making, Citizenship, and Civic Constitutionalism, in Comparative Constitutional Theory, supra note 4. 
maintenance is a task handed off to lawyers and courts which, in turn, corrosively attenuates the relationship between citizens and their constitutional order.

The American Constitution plays an outsized role in constitutional theorizing even though it is increasingly an outlier in the broader stream of global constitutionalism. Mark Graber critically examines the scholarship on American constitutional exceptionalism. ${ }^{77}$ The conventional wisdom is that the United States is different because its constitutional order is much older than the globalist and internationalist constitutional order that emerged after World War II. Americans look to the past and the founding whereas Europeans, for example, look to internationalist understandings of constitutionalism. Graber persuasively argues that America's constitutional differences are driven not by its antiquity but by constitutional politics that have been decisively shaped by the problem of race. Constitutional politics in other polities, on the other hand, is considerably more heterogeneous.

Authoritarian constitutionalism, not unlike unwritten constitutionalism, is largely ignored by comparative constitutional scholars. Wen-Chen Chang and David Law argue that it is a mistake to define constitutionalism without taking China into account. ${ }^{78}$ The authors note that there is considerable disagreement among scholars whether China has embraced constitutionalism or not. The authors reject a "merit badge" definition of constitutionalism that defines the term by asking whether a polity has satisfied normative criteria pulled from the "best practices" of Western democracies. Even though China lacks judicial review and its written constitution is, at best, only weakly implemented, the authors argue that China's written constitution serves as a "constructive irritant" that threatens to upset politics. The distance between China's political practices and the promises found in its constitutional text can become a focal point of popular mobilization and serve to channel disagreement.

\section{CONCLUSIONS}

In a famous essay praising the efforts of his contemporaries, the framers of the American Constitution, Noah Webster explained, "Experience is the best instructor-it is better than a thousand theories."79 The comment was made in connection with Webster's endorsement of the six-year term of office for members of the Senate, although its applicability extended well beyond that one provision. Considering the Senate's design, a "capital excellence of the proposed constitution", he boldly invoked the "history of every government on earth" before proclaiming, "I appeal only to our own experience in America." 80

77 Mark Graber, Race and American Constitutional Exceptionalism, in Comparative Constitutional Theory, supra note 4.

78 Wen-Chen Chang and David Law, Constitutional dissonance in China? in Comparative Constitutional Theory, supra note 4.

79 Noah Webster, Remarks Upon the Constitutional Convention, in Defending the Constitution: Selections From Writings By Webster, Jay, Hamilton, Madison and Jefferson 8 (Richard B. Bernstein ed., 1987).

80 Id. 
Yet in that same essay Webster also said:

In the formation of such a government, it is not only the right, but the indispensable duty of every citizen to examine the principles of it, to compare them with the principles of other governments, with a constant eye to our particular situation and circumstances, and thus endeavor to foresee the future operations of our own system, and its effects upon human happiness. ${ }^{81}$

A parochial reliance on experience and an aversion to theory would thus appear to be compatible with the injunction to scrutinize the principles by which peoples in faraway places govern their societies.

Perhaps if Webster's name were not synonymous with the dictionary one might be inclined to see in these reflections some confusion in the author's word selection. Why emphasize the insularity of experience while insisting on an obligatory exercise in comparative evaluation? Why disparage theorizing while acknowledging the principled structure of governmental organization?

Making sense of the ostensible difficulties in Webster's thinking begins with the recognition that his references to theory and experience meant something quite different from how those terms are employed in the pages of this volume. Thus, today's accounts of experience and theory often embody a conceptualization of the latter as embodying a set of universal truths from which the attributes of a genuine constitution may be deduced. The prevailing view has it that constitutions represent a blend of characteristics revealing what is particular to the specific constitutional culture as well as what is endemic to the genus constitutionalism. In this account the diversity of constitutional experience serves chiefly to validate the ubiquity of the features that mark constitutions as entities of a certain type.

By contrast, Webster recommended studying the principles of other governments at a time when the term constitution was undergoing a paradigm shift. When the United States Constitution was drafted, the unwritten British constitution was considered the very best example of a government that balanced power and liberty. ${ }^{82}$ Following the promulgation of the American Constitution, written constitutions spread throughout the Atlantic world transforming how constitutions were understood. ${ }^{83}$ Accordingly, it is very likely that in asking for a comparison of other government's principles with those of the newly constituted American government, Webster would have been confident that "our own experience in America" would prove more conducive to "human happiness" than the many political orders whose lack of regard for the "rational and

${ }^{81} I d$. at 6 . Webster might have had James Madison in mind, for as detailed by Jack Rakove, prior to the Federal Convention, Madison "undertook a course of reading in the history of 'ancient and modern confederacies." Jack N. Rakove, Original Meanings: Politics and Ideas in the Making of the Constitution 42 (1996). Webster may also have been thinking of the delegates in Philadelphia for whom the British constitution was a critical model in analyzing the proposed constitution. Margaret A. Banks, Drafting the American Constitution-Attitudes in the Philadelphia Convention Towards the British System of Government, 10 Am. J. Legal Hist. 15 (1966).

82 Giovanni Sartori, Constitutionalism: a Preliminary Discussion, 56 Pol. Sci. Rev. 853 (1962); Gordon S. Wood, The Creation of the American Republic, 1776-1787, 4-44 (1998).

83 Schor, The Federalist, supra note 3. 
social" standing of their peoples could justifiably be inferred from their lack of a constitution, or at least one directly expressive of the constituent power. ${ }^{84}$

In appealing to American experience Webster was only doing what until fairly recently was the norm for many-especially Americans-whose interest in governing arrangements extended beyond the borders of the United States: assume that what had been created in Philadelphia in the late eighteenth century should serve as the measuring rod for constitutional design and practice in other places. We can be reasonably sure that absent from the theories Webster so pointedly belittled in 1787 was the one we feature here; indeed, the empirical necessities for comparative constitutional theory's existence were insufficiently developed to fulfill this purpose. Commensurate, however, with the later proliferation of constitutional experience, the activity of thinking theoretically about things constitutional could no longer avoid comparative theoretical reflection on "the principles of other governments." 85 What is more, such activity was bound to dispel the notion that one's own constitutional arrangements were the only ones that could reasonably accomplish the goals of constitutionalism.

This volume's contributions confirm the accuracy of this prognostication, particularly with respect to any lingering constitutionally-grounded American pretensions. Noteworthy in this regard are the geographical and cultural backgrounds of the contributors, most of whom are based in places other than the United States, or at least connected to such places by birth and upbringing. England, Australia, Argentina, Canada, Scotland, Spain, Hungary, New Zealand, Germany, Israel, Puerto Rico, South Africa and China - an impressive diversity of experience from which to restrain any inclination to hasty indulgence in constitutional home cooking.

Still, no echoes will be found in these pages of Webster's "appeal only to our own experience." 86 To be sure, some of the chapters are more driven than others by concerns that flow from the lessons of local experience, and it is possible to discern in them a diffident outlook on the potential payoffs of comparative constitutional theorizing. Yet even as they tend towards generalizations that are more circumscribed by time and space than are evident elsewhere in this book, they remain open to a more robust and capacious agenda of theory building.

In the end, what these chapters have in common is what now renders comparative constitutional theory a permanent presence in the scholarly lives of a burgeoning intellectual cohort: an acknowledgment of the ubiquitous condition of constitutional imperfection. Thus, Publius' restrained conclusion in his final essay was hardly the first modern appreciation of its significance, as is clear from Montesquieu's invocation of a well-known ancient example: "Solon being asked if the laws he had given to the Athenians were the best, he replied, 'I have given them the best they were able to bear." 87 Or as Noah Webster put it in his summary remarks about a constitution he believed to be "an improvement on the best constitutions the world ever saw", "Perfection is not the lot of humanity." 88

84 Noah Webster, American Dictionary of the English Language (1828).

85 Webster, supra $\mathrm{n} 79$, at 6.

86 Id. at 8 .

87 Baron de Montesquieu, The Spirit of the Laws (1966).

88 Webster, supra note 79 , at 39, 38. 
Gary Jacobsohn and Miguel Schor - 9781784719135 Downloaded from PubFactory at $04 / 26 / 2023$ 12:13:19PM via free access 